Check for updates

Cite this: RSC Adv., 2019, 9, 8025

Received 30th January 2019

Accepted 22nd February 2019

DOI: 10.1039/c9ra00808j

rsc.li/rsc-advances

\section{Tannic acid-stabilized gold nano-particles are superior to native tannic acid in inducing ROS- dependent mitochondrial apoptosis in colorectal carcinoma cells via the p53/AKT axis $\uparrow$}

\begin{abstract}
Sayoni Nag, Krishnendu Manna and Krishna Das Saha (D) *
Gold nanoparticle formulated tannic acid (AuNP-TA) was synthesized, and its anticancer activity was compared to that of free tannic acid (TA). The half maximal inhibitory concentration $\left(\mathrm{IC}_{50}\right)$ was reduced by half when cell lines were treated with AuNP-TA as compared to IC $C_{50}$ values upon free TA treatment. Both showed better cytotoxic activity in HCT116 cell line as compared to MCF7 and HepG2. AuNP-TA induced death of HCT116 cells was associated with characteristic apoptotic changes. At the same treatment dose, AuNP-TA generated more ROS, caused a more extensive DNA damage and promoted higher expression of p53 and p21 than TA. Treatment with AuNP-TA regulated generation of p53 and ROS bi-directionally. Binding studies showed that TA lowered the expression of Akt, which inhibited the survival of colon cancer cells. Also, cell cycle arrest at the G2/M phase, enhanced expression of caspase3/9, Bak, and Bax, loss of mitochondrial membrane potential, and enhanced level of cytosolic cytochrome $c$ were observed in AuNP-TA treated HCT116 cells. Thus, AuNP-TA is more efficient than TA in inducing apoptotic cell death of HCT116 cells via the ROS/P53/Akt axis.
\end{abstract}

\section{Introduction}

Phytochemicals have been used historically to treat cancer because they are safe, readily available and non-toxic. ${ }^{1}$ However, in spite of their potent anticancer characteristics, they exhibit major disadvantages, such as poor bio-availability and low water solubility. ${ }^{2}$ Polyphenols are secondary metabolites that act as signaling molecules during growth and development and provide defense against microbe and herbivore attacks. Polyphenols exhibit anticancer activity both in vivo and in vitro. ${ }^{3}$ Tannic acid (TA), a polyphenol, has also been reported to exert anticancer, ${ }^{4}$ pro-oxidant, ${ }^{5}$ antimicrobial ${ }^{6}$ and antiviral ${ }^{7}$ effects. It is toxic at high doses and leads to hepatic necrosis. As described in a previous study, a complete uptake of tannic acid via rat gut wall was prevented. ${ }^{8}$

There are reports of polyphenols being modified in the small intestine, colon and liver, where most conjugation occurs., ${ }^{\mathbf{9 1 0}}$ All these modifications profoundly affect biological activity of polyphenols. As a result, the compounds reaching the cells and tissues are chemically, biologically and functionally different from the original dietary form. ${ }^{\mathbf{1 1}}$ The field of nanotechnology has overcome many of these limitations. Phytochemicals are

Cancer Biology and Inflammatory Disorder Division, CSIR-Indian Institute of Chemical Biology, 4 Raja S.C. Mullick Road, Kolkata-700032, West Bengal, India. E-mail: krishna@iicb.res.in; Fax: +91 332473 5197; Tel: +91 3324995810

$\dagger$ Electronic supplementary information (ESI) available. See DOI: 10.1039/c9ra00808j more soluble when delivered by nanocarriers and show a better effect on cancer cells as compared to their free form. ${ }^{12}$

Metal nanoparticles are important because their surface area and the proportion of surface atoms are high. ${ }^{13}$ The biological effects of GNPs (gold nano-particles) are significant for human health and cosmetics applications. ${ }^{14}$ In the $18^{\text {th }}$ century, the Egyptians used gold metal, solubilized in water, for the betterment of mental and spiritual health. Even in rural villages, peasants cooked their rice with gold pellets to replace the minerals in the body via intake of food. ${ }^{15}$ Gold nano conjugated polyphenols are stable, non-agglomerated and biologically active. ${ }^{16}$ GNPs also exhibit special properties, such as surface plasmon resonance (SPR) and the ability to bind to thiol and amine groups, thus, permitting surface modification and biomedical application. ${ }^{17}$ The in vivo and in vitro cytotoxic effects of GNPs have been reported in several studies, some of which showed that GNPs exhibit anticancer properties via the induction of oxidative stress by generating reactive oxygen species, ultimately leading to death of the cancerous cells. ${ }^{18}$

Reactive oxygen species (ROS) is an essential regulator of DNA damage. ${ }^{19}$ Mutation in p53 gene is the most common mutation in human cancer cells that plays a vital role in the genomic examination. It is needed for the cell cycle arrest because it provides the necessary time for DNA repair. The cell cycle can resume after DNA damage has been repaired. Otherwise, the cells are destructed via apoptosis. p53 mediates cell cycle arrest and apoptosis via its effector $\mathrm{p} 21 .^{20}$ 
PI3K (phosphatidylinositol 3-kinase)/AKT (protein kinase B) signaling is often disturbed in human cancers with AKT being a central constituent of the pathway, influencing various processes that are involved in cell survival and tumorigenesis. Targeting AKT is, therefore, an attractive anti-cancer strategy with multiple AKT inhibitors now in use at different stages of clinical development. ${ }^{21}$ Many anticancer drugs, like tamoxifen and 5-fluorouracil, operate via upregulation of ROS and p53 and downregulation of Akt. ${ }^{22,23}$

It was stated in previous reports that TA leads to apoptosis via ROS generation in human glioma cells. ${ }^{24}$ It has been suggested that the combined effect of resveratrol and TA triggers apoptosis in colon cancer cells. ${ }^{25}$ However, the cellular pathway by which TA alone leads to colon cancer cell death and the role of ROS and signaling cascade of colon cancer cells have not been explored yet. Thus, this study aimed to investigate the enhanced anti-cancer activity of tannic acid in HCT116 cells with the exploration of the ROS-p53-Akt pathway and to compare its anti-cancer efficacy with that of tannic acid-stabilized gold nanoparticles.

\section{Materials and methods}

\section{Chemicals}

Tetrachloroauric acid $\left(\mathrm{HAuCl}_{4}\right), \mathrm{TA}$, propidium iodide (PI), caspase-3 and caspase-9 activity assay kit were bought from Sigma Aldrich (USA). 3-(4,5-Dimethylthiazol-2-yl)-2,5diphenyltetrazolium bromide (MTT), Annexin-V/FITC kits and rhodamine 123 were obtained from Calbiochem. All cell lines were bought from National Centre For Cell Science (NCCS), Pune, Govt. of India. Fetal bovine serum, Dulbecco's Modified Eagle Medium, Pen-strep (penicillin and streptomycin) antibiotic, and trypsin were obtained from Gibco BRL (Grand Island, USA). Cell culture plastic wares were obtained from NUNC (Denmark) and protein assay reagent, BCA, was purchased from Pierce. DAPI (4',6-diamidino-2-phenylindole dihydrochloride), acridine orange $(\mathrm{AO})$, and ethidium bromide (EtBr) were supplied by Invitrogen (California). All primary and secondary antibodies were purchased from Cell Signaling Technology (CST). All other reagents were bought from Sigma-Aldrich Company, USA.

\section{Preparation of AuNP-TA}

Reduction of $\mathrm{Au}^{3+}$ ions to $\mathrm{Au}^{0}$ was performed by heating the solution of $20 \mathrm{ml}$ of $0.25 \mathrm{mM} \mathrm{TA}$ at $45^{\circ} \mathrm{C}$ for $15 \mathrm{~min}$ and adding $100 \mu \mathrm{l}$ of $30 \mathrm{mM} \mathrm{HAuCl}$ dropwise. A deep pink solution was obtained within $10 \mathrm{~min}$. The solution was stirred on a magnetic stirrer for $1 \mathrm{~h}$ without heating. AuNP-TA nanoparticles were centrifuged at $14000 \mathrm{rpm}$ for $30 \mathrm{~min}$ to remove any unconjugated TA that remained in the supernatant. The amount of unbound free TA in the supernatant was determined to be 0.642 $\mu \mathrm{M}$ by monitoring the UV absorption at $250 \mathrm{~nm}$ using the extinction coefficient of $\varepsilon=27200 \mathrm{M}^{-1} \mathrm{~cm}^{-1}$. Thus, the final concentration of conjugated TA on AuNP was $0.2482 \mathrm{mM}$. The amount of unbound free AuNP in the supernatant was determined to be $1.134 \mu \mathrm{M}$ by monitoring the UV-Vis absorption at
$450 \mathrm{~nm}$ using the extinction coefficient of $\varepsilon=$ $72246.8 \mathrm{M}^{-1} \mathrm{~cm}^{-1}$. Thus, the final concentration of AuNP was $29.739 \mathrm{mM}$.

Next, the obtained pellet was washed with double distilled de-ionized water and suspended in $1 \mathrm{ml}$ of PBS before administration to cells.

\section{Characterization of AuNP-TA}

AuNP-TA was characterized using techniques like UV absorbance, DLS, AFM, and FTIR according to the standard protocol.

\section{Cell culture}

HepG2 (human hepatocellular carcinoma), MCF-7 (human breast cancer), and HCT 116 (human colorectal carcinoma) cells were cultured in DMEM, supplemented with $10 \%$ fetal bovine serum (FBS) and $1 \%$ pen-strep at $37{ }^{\circ} \mathrm{C}$ in a humidified environment under $5 \% \mathrm{CO}_{2}$. After $60-80 \%$ confluency, cells were collected using $0.05 \%$ trypsin and $0.50 \mathrm{mM}$ EDTA in phosphate buffered saline (PBS, $\mathrm{pH}=7.4$ ) and seeded at a necessary density to allow them to grow well for a day before performing the experimentation.

\section{MTT assay}

MTT assay was performed to determine cell viability. The cells $\left(1 \times 10^{5}\right.$ per well $)$ were seeded in 96 well plates and treated with different concentrations of TA and AuNP-TA for $24 \mathrm{~h}$. Four hours after adding MTT, the generated purple formazan was solubilized in DMSO, and the absorbance was measured at $595 \mathrm{~nm}$ using an ELISA (enzyme-linked immune sorbent assay) reader.

\section{Fluorescence microscopy}

For detecting the damage to nuclear or chromatin condensation, untreated and treated cells $\left(3 \times 10^{4}\right.$ per well $)$ were stained with $10 \mu \mathrm{g} \mathrm{ml}{ }^{-1}$ DAPI. Cells were also stained with AO/EB to distinguish the live, apoptotic and necrotic ones and observed under a fluorescence microscope (Olympus, Tokyo, Japan). Images were obtained at excitation and emission wavelengths of 488 and $550 \mathrm{~nm}$.

\section{Quantification of apoptosis using Annexin-V}

Apoptosis was detected using an Annexin-V FITC apoptosis detection kit. Cells were treated with or without AuNP-TA and then washed and stained with PI and Annexin-V-FITC according to the instructions in the kit. The percentage of live, apoptotic and necrotic cells was determined using flow cytometry (Beckton Dickinson, San Jose, CA, USA).

\section{Measurement of ROS generation}

ROS generation was measured using $\mathrm{H}_{2}$ DCF-DA. After treatment with or without AuNP-TA in a time-dependent manner, the cells were incubated with $10 \mathrm{mM} \mathrm{H}_{2}$ DCF-DA for $20 \mathrm{~min}$ at room temperature. The intracellular reactive oxygen species (ROS) causes oxidation of $\mathrm{H}_{2}$ DCF-DA to $2^{\prime}, 7^{\prime}$-dichlorofluorescein (DCF), a fluorescent compound. Cell pellets were 
suspended in $500 \mu \mathrm{l}$ PBS, and samples were analyzed at excitation and emission wavelengths of $480 \mathrm{~nm}$ and $525 \mathrm{~nm}$ using a spectrofluorometer and a flow cytometer (Becton Dickinson, San Jose, CA, USA).

\section{Cell death detection assay}

Quantification of histone-associated DNA fragments (monoand oligo-nucleosomes) in the cytoplasm after inducing cell death with TA and AuNP-TA was performed using ELISA kit (Sigma-Aldrich, St. Louis, USA) according to the manufacturer instructions.

\section{Cell cycle analysis}

After treatment with TA and AuNP-TA, cells were pelleted and fixed overnight in $70 \%$ ethanol at $4{ }^{\circ} \mathrm{C}$. Next day the cells were pelleted and suspended in PBS containing $25 \mu \mathrm{g} \mathrm{ml}{ }^{-1}$ RNase and Triton X-100 (0.5\%) and incubated for $1 \mathrm{~h}$ at $37^{\circ} \mathrm{C}$. Next, they were stained with $50 \mu \mathrm{g} \mathrm{ml}^{-1} \mathrm{PI}$ at $4{ }^{\circ} \mathrm{C}$ for $15 \mathrm{~min}$ and analysed using flow cytometry. A total of $1 \times 10^{4}$ cells were counted.

\section{Caspase activity assay}

Levels of active caspases were assayed using colorimetric assay kits (Calbiochem) following the instructions on the kit.

\section{Western blot analysis}

The cell lysate proteins were separated using 12\% SDS-PAGE (sodium dodecyl sulfate-polyacrylamide gel electrophoresis) and transferred to PVDF (polyvinylidene fluoride) membranes (Millipore, Bedford, MA) using standard electroblotting techniques.

\section{Confocal microscopy}

The effect of TA and AuNP-TA on levels of p53 and p21 expression in cells was examined employing immunocytochemical analysis using standard techniques and evaluated under Olympus FV10i automated laser scanning confocal microscope.

\section{Measurement of mitochondrial membrane potential}

In order to measure the mitochondrial membrane potential, the treated or untreated cells were washed and incubated with rhodamine $123\left(5 \mu \mathrm{g} \mathrm{ml}^{-1}\right)$. Emission at $535 \mathrm{~nm}$ was measured using a spectrofluorometer (LS50B; Perkin Elmer).

\section{Protein expression determination via flow cytometry}

To analyse protein expression, cells were fixed with $4 \%$ paraformaldehyde for $15 \mathrm{~min}$, perforated with $0.05 \%$ Triton-X for $10 \mathrm{~min}$ and centrifuged. The cell pellet was washed with PBS, labeled with primary and fluorochrome-conjugated secondary antibodies and analyzed using a flow cytometer.

\section{Docking studies}

The SwissDock online based server was used for performing docking studies of our compound and other proteins.

\section{Statistical analysis}

All values are expressed here as mean \pm SD. Statistical significance was calculated between control and treatment groups using oneway analysis of variance (ANOVA). Data were considered to be statistically significant when $P$ values were found to be $<0.01$.

\section{Results}

\section{AuNP-TA characterization}

AuNP-TA exhibited a characteristic rose pink color (Fig. 1A). The presence of the surface plasmon resonance band of AuNP-TA at $\sim 537 \mathrm{~nm}$ confirmed ${ }^{26}$ its identity (Fig. 1B). As determined by atomic force microscopy measurements, the surface topology of AuNP-TA particles was uniform; they had a spherical shape with size ranging between $60-80 \mathrm{~nm}$ (Fig. 1C and D). The size of AuNP-TA particles, obtained from the differential light scattering study, ranged between 68.06-78.82 nm (Fig. 1E).

FTIR analysis of free TA and AuNP-TA was performed to analyse the involvement of various functional groups. A broad peak was seen at $3400 \mathrm{~cm}^{-1}$ for TA and $3398 \mathrm{~cm}^{-1}$ for AuNP-TA, attributed to $\mathrm{O}-\mathrm{H}$ bond stretching and consistent with the presence of alcoholic and phenolic compounds. One more peak at $1643 \mathrm{~cm}^{-1}$ for TA and $1641 \mathrm{~cm}^{-1}$ for AuNP-TA indicated the presence of amide $(\mathrm{C}=\mathrm{O})$ and alkene $(\mathrm{C}=\mathrm{C})$ groups. Smaller peaks, detected at $1209 \mathrm{~cm}^{-1}$ for TA and $1211 \mathrm{~cm}^{-1}$ for AuNPTA, confirmed the presence of esters. A major difference was observed between the two peaks at $3398 \mathrm{~cm}^{-1}$ and $1641 \mathrm{~cm}^{-1}$ for AuNP-TA (Fig. 1F), indicating the role of $\mathrm{C}=\mathrm{O}$ and $\mathrm{O}-\mathrm{H}$ bonds in the reduction of $\mathrm{Au}(\mathrm{III})$ ions to $\mathrm{Au}$ atoms. ${ }^{27}$

\section{Effect of TA and AuNP-TA on the growth of cancer cells}

Treatment with TA and AuNP-TA, ranging in concentration from 0 to $200 \mu \mathrm{M}$, of three human cancer cell lines, MCF-7, HCT116, and HepG2, for $24 \mathrm{~h}$ showed different degrees of cell death, as shown in Fig. $2 \mathrm{~A}(\mathrm{a}-\mathrm{c})$. For comparison with free TA, we used the same dose of AuNP-TA. Both showed higher cytotoxicity in HCT116 cells $\left(\mathrm{IC}_{50}\right.$ values of $48.37 \pm 3.24 \mu \mathrm{M}$ and $23.21 \pm 2.45 \mu \mathrm{M})$ than in HepG2 cells $\left(\mathrm{IC}_{50}\right.$ of $105.5 \pm 5.6$ $\mu \mathrm{M}$ and $57.6 \pm 3.1 \mu \mathrm{M})$ or MCF-7 $\left(\mathrm{IC}_{50}\right.$ of $72.35 \pm 3.7 \mu \mathrm{M}$ and $39.25 \pm 2.6 \mu \mathrm{M})$. Hence, we have conducted further studies in HCT116 cell line using $50 \mu \mathrm{M}$ dose of AuNP-TA (the concentration of TA on AuNP), the dose which resulted in optimum cell death.

\section{TA and AuNP-TA-induced apoptosis and enhanced Annexin V positive cells}

AuNP-TA treated HCT116 cells were studied to determine the mechanism of cell death. Apoptosis is often desired for the death of cancer cells. ${ }^{28}$ Cells, treated with $50 \mu \mathrm{M}$ TA or AuNP-TA for $24 \mathrm{~h}$, showed characteristic features of apoptosis-like rounding and shrinking under a light microscope. ${ }^{28}$ Fluorescence microscopy study of treated HCT cells using DAPI staining showed intact blue nuclei in the control group and brighter fragmented nuclei in the treated cells. Use of $\mathrm{AO} / \mathrm{EtBr}$ for staining revealed the presence of whole green nuclei in the control group cells but greenish yellow, orange and reddish 
A

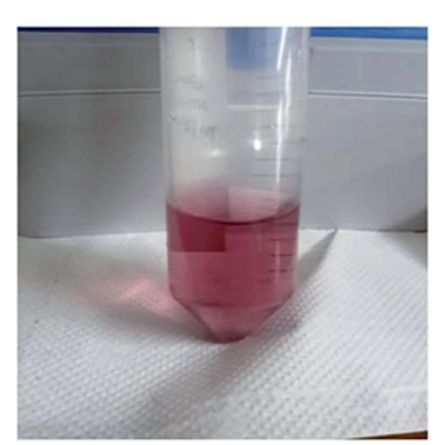

C

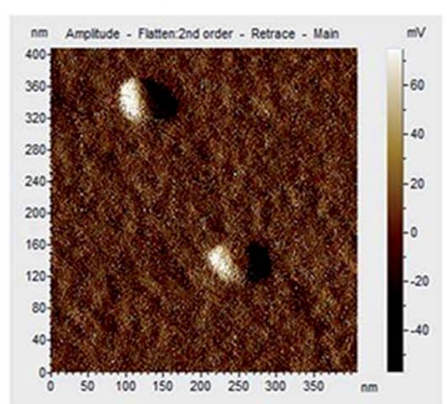

B

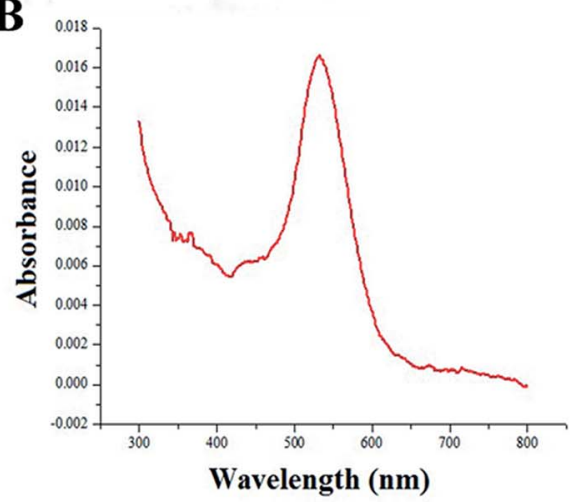

D

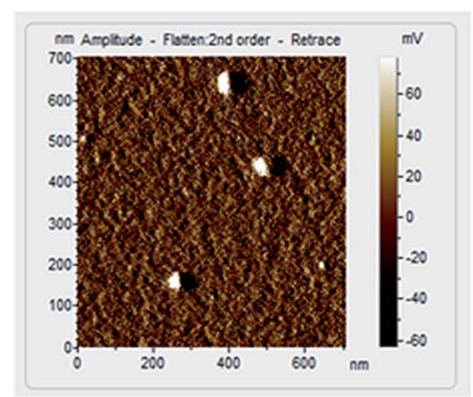

$\mathbf{E}$

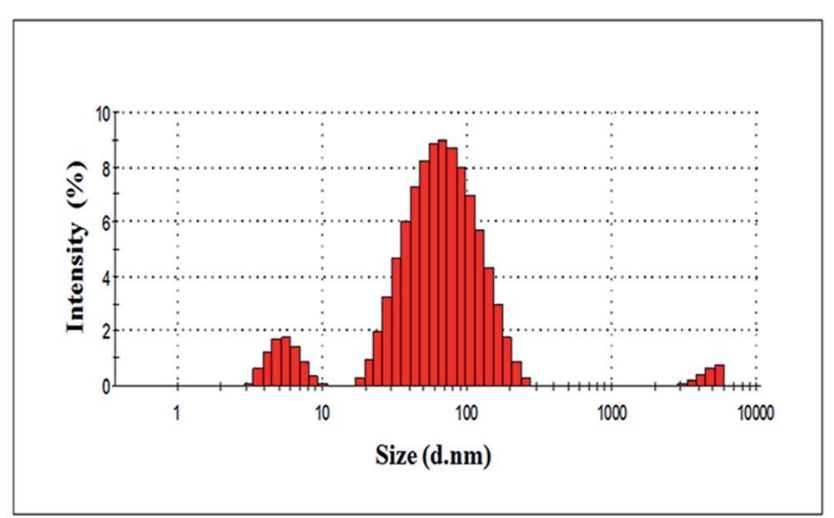

F
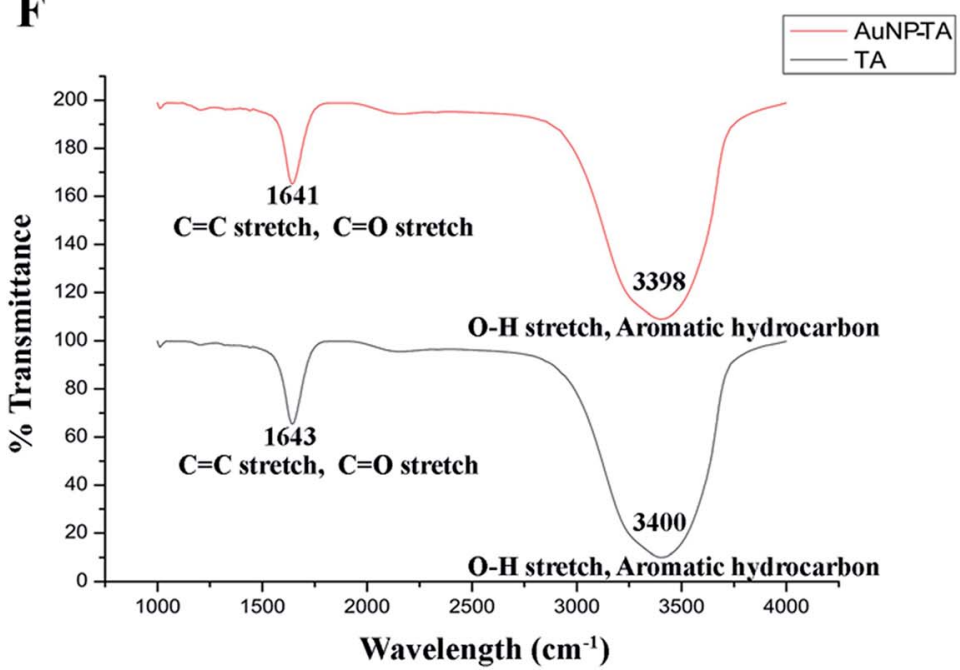

Fig. 1 (A) Rose pink color AuNP-TA; (B) UV-Vis spectrum of AuNP-TA; (C and D) AuNP-TA particle surface topology determination using AFM; (E) particle size distribution for AuNP-TA determined by DLS; (F) FTIR spectra of free TA and AuNP-TA solutions. 

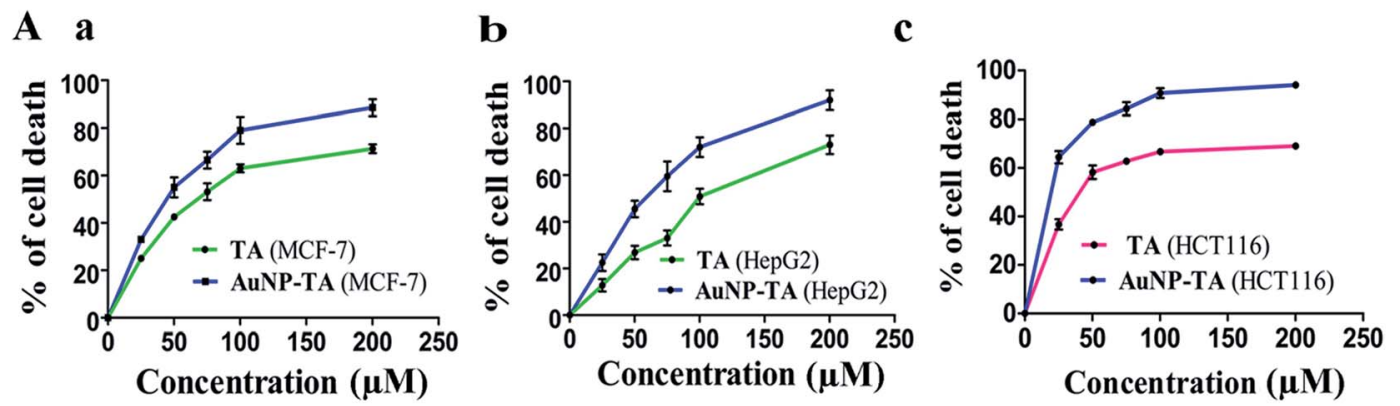

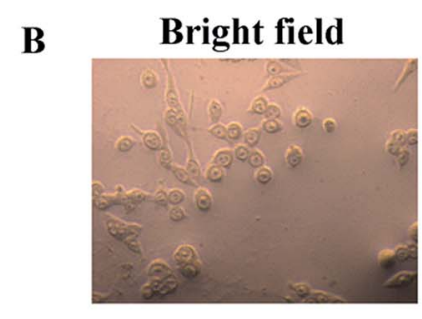

A.O/Et.Br
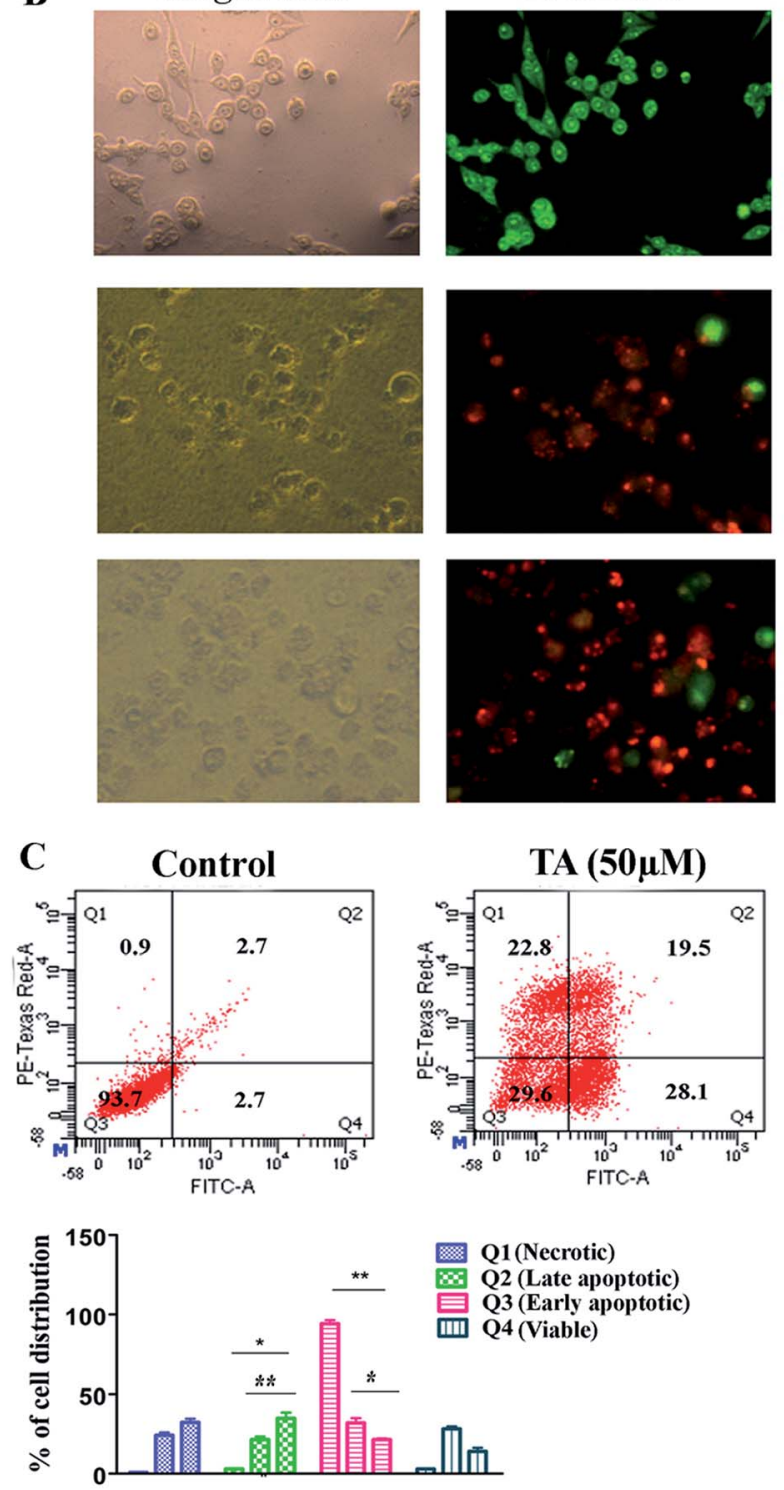

DAPI

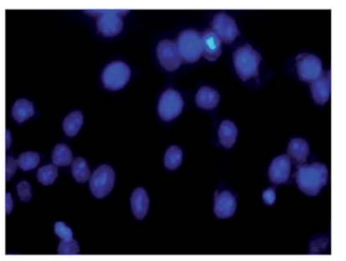

\section{Control}

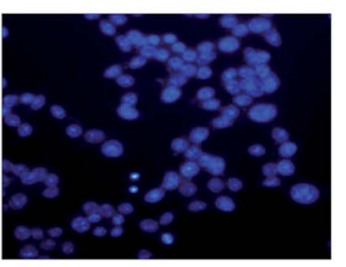

TA

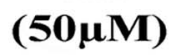

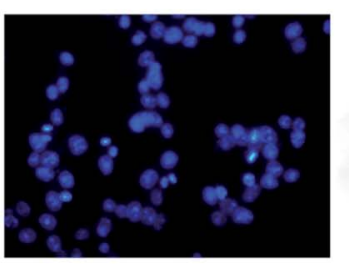

AuNP-TA

$(\mathbf{5 0 \mu M )}$

Fig. 2 (A) Growth inhibitory effect of TA and AuNP-TA on different cancer cells: (a) MCF7, (b) HepG2 and (c) HCT116. Cells were treated with different concentrations $(0,25,50,100,200 \mu \mathrm{M})$ of TA and AuNP-TA for $24 \mathrm{~h}$ and viability was measured using MTT assay. The data are represented as mean \pm SD from triplicate independent experiments. (B) Morphological and nuclear changes in HCT 116 cells after $50 \mu \mathrm{M}$ of TA and AuNP-TA treatment for $24 \mathrm{~h}$. Left column: morphological changes seen under a light microscope. Middle and right column: nuclear changes seen under a fluorescence microscope after AO/EB and DAPI staining, respectively. Scale bar $=20 \mu \mathrm{m}$. (C) Effect of $50 \mu M$ of TA and AuNP-TA treatment for $24 \mathrm{~h}$ on Annexin V-FITC binding in HCT116 cells. The result represents the mean \pm SD from triplicate independent experiments.

fragmented nuclei in treated cells. ${ }^{29}$ The effect of apoptosis was more profound when cells were treated with AuNP-TA rather than with TA (Fig. 2B).
At the beginning stage of apoptosis, phosphatidylserine is exposed from the inner to the outer membrane. The content of phosphatidylserine in the outer membrane of HCT116 cells, 
following treatment with $50 \mu \mathrm{M}$ of TA or AuNP-TA for $24 \mathrm{~h}$, was assessed by flow cytometric analysis using Annexin-V/FITC. ${ }^{30}$ It was determined that the percentage of viable cells was lowered by $64.1 \%$ and $73.1 \%$, respectively, while the total number of apoptotic cells increased by $25.4 \%$ and $13.5 \%$, respectively, in LR (early apoptotic quadrant) and by $16.8 \%$ and $30.6 \%$ in UR (late apoptotic quadrant). This study, therefore, confirmed that both TA and AuNP-TA-induced apoptosis in HCT116 cells, but AuNP-TA increased the percentage of cells in UR more by $13.8 \%$ as compared to TA at the same dose (Fig. 2C).

\section{AuNP-TA treatment promotes enhanced ROS generation and ROS dependent cell death}

Previous reports suggested that polyphenols can kill cancer cells by inducing ROS generation. ${ }^{31}$ Also, gold nanoparticle treated carcinoma cells displayed an increased generation of ROS, ultimately leading to the death of cancerous cells. ${ }^{18}$ After treatment of HCT116 cells with different concentrations of TA and AuNP-TA (0$200 \mu \mathrm{M})$ at different time points $(6,12$ and $24 \mathrm{~h})$ and measuring ROS generation using a spectrofluorimeter, it was observed that ROS generation in HCT116 cells increased with dose and time. Also, around 1.9 times higher ROS generation was observed when cells were treated with $50 \mu \mathrm{M}$ of AuNP-TA rather than TA (Fig. 3A and $\mathrm{B}$ ).

ROS generation, which can lead to cancer cell death via apoptosis, ${ }^{32}$ was studied next in HCT116 cells using the ROS inhibitor NAC ( $N$-acetyl-L-cysteine) ${ }^{33}$ We found that at $24 \mathrm{~h}$, it increased by 9 and 67.8 times as compared to control when cells were treated with $50 \mu \mathrm{M}$ of TA and $50 \mu \mathrm{M}$ of AuNP-TA. But pretreatment with 100,200 , or $400 \mu \mathrm{M}$ of NAC gradually lowered the level of ROS generation, induced by AuNP-TA, by 3.0, 4.29 and 8.69 fold, respectively (Fig. 3C). Also, the percentage of dead HCT116 cells after the $50 \mu \mathrm{M}$ AuNP-TA treatment decreased by $33.8 \%$ and $47.4 \%$ after pre-treatment with 100 and $200 \mu \mathrm{M}$ NAC, respectively (Fig. 3F).

\section{TA and AuNP-TA cause ROS dependent DNA damage in HCT116 cells}

ROS are capable of inducing DNA damage in cells. ${ }^{34,35}$ After the treatment of HCT116 cells with different concentrations of TA and AuNP-TA $(0-200 \mu \mathrm{M})$ at different time points $(6,12$ and 24 h), DNA fragmentation was measured using a spectrofluorimeter to find that it increased with dose and time. O.D. of untreated cells was 0.212 , but 0.660 for $50 \mu \mathrm{M}$ TA and 0.993 for $50 \mu \mathrm{M}$ AuNP-TA treated HCT116 cells after $24 \mathrm{~h}$. These values decreased by 1.766 -fold and 2.56 -fold when cells were treated with 100 and $200 \mu \mathrm{M}$ NAC before the treatment with $50 \mu \mathrm{M}$ AuNP-TA, showing that the increase in ROS generation leads to increased DNA damage, which was decreased upon inhibition of ROS production by NAC (Fig. 3D and E).

\section{TA and AuNP-TA-induced DNA damage leads to p53 and p21 upregulation and translocation to the nucleus}

DNA damage caused by ROS leads to activation of $\mathrm{p} 53 .^{36,37}$ The increased capability of p53 to bind DNA mediates transcriptional activation of many downstream genes, most importantly, p21, whose products trigger cell-cycle arrest. $^{38}$ As expected, western blot results indicated a higher expression of p53 and p21 when cells were treated with $50 \mu \mathrm{M}$ AuNP-TA rather than 50 $\mu \mathrm{M}$ TA. AuNP-TA induced higher expression levels of p53 and its downstream product $\mathrm{p} 21$. When cells were treated with p53 inhibitor pifithrin- $\alpha,{ }^{39}$ the expression levels of p53 and its downstream product p21 decreased (Fig. 4A).

P53 synthesis occurs in the cytoplasm, and it is transported into the nucleus to activate transcription of downstream targets after its exposure to cellular stress. ${ }^{40,41}$ Also, p21 enters the nucleus to affect downstream cell cycle arrest. In case of cells, co-incubated with primary p53 and p21 antibodies and developed with FITC and TRITC labeled secondary antibodies, respectively, co-translocation in the nuclei was observed for both proteins in $50 \mu \mathrm{M}$ TA and $50 \mu \mathrm{M}$ AuNP-TA treated cells; in the untreated cells, p53 and p21 were found mainly in the cytoplasm. However, more profound co-localization of p53 and p21 proteins was observed in cells, treated with AuNP-TA rather than TA (Fig. 4B).

As revealed by MTT assay, the percentage of dead AuNP-TA treated HCT116 cells was found to decrease by 33.8 and $45.4 \%$ after treatment with 10 and $20 \mu \mathrm{M}$ PFT- $\alpha$, respectively, before the $50 \mu \mathrm{M}$ AuNP-TA treatment (Fig. 4C).

\section{TA and AuNP-TA induced ROS generation and p53 upregulation affect each other bi-directionally}

Next, we wanted to determine whether p53 also controlled ROS generation $^{42}$ or just ROS controls p53 when HCT116 cells were treated with AuNP-TA. Spectrofluorimetry measurements showed decreased ROS generation when HCT116 cells were pretreated with 10 and $20 \mu \mathrm{M}$ pifithrin- $\alpha$, followed by treatment with $50 \mu \mathrm{M}$ AuNP-TA, as compared to ROS generation when HCT116 cells were treated with $50 \mu \mathrm{M}$ AuNP-TA (Fig. 5A). Western blot data showed a decrease in p53 expression in cells treated with $50 \mu \mathrm{M}$ AuNP-TA when they were pre-treated with 100 and $200 \mu \mathrm{M}$ of NAC (Fig. 5B).

\section{TA and AuNP-TA cause G2/M cell cycle arrest in HCT116 cells}

To determine ROS mediated cell cycle arrest, ${ }^{\mathbf{4 3 , 4 4}}$ we have tested the cell cycle status after treating cells with $50 \mu \mathrm{M}$ TA or $50 \mu \mathrm{M}$ AuNP-TA, and cells pre-treated with 10 and $20 \mu \mathrm{M}$ PFT- $\alpha$ also with $50 \mu \mathrm{M}$ AuNP-TA. G2/M cell cycle arrest occurred after TA and AuNP-TA treatment as the proportion of cells in G2/M phase decreased by $4.9 \%$ for TA and $19.1 \%$ for AuNP-TA groups but increased by $8.8 \%$ and $10.6 \%$ in cells, pre-treated with 10 and $20 \mu \mathrm{M}$ PFT- $\alpha$ (Fig. 6A).

Protein p53 regulates expression of cyclins, controlling the cell cycle. ${ }^{45,46}$ Expression levels of cyclin A, cyclin B1, and CDK1 (Cyclin-Dependent Kinase) decreased, the extent being more pronounced when cells were treated with $50 \mu \mathrm{M}$ of AuNP-TA and not TA. But there was an increase in the expression levels when cells were pre-treated with 10 or $20 \mu \mathrm{M}$ of pifithrin- $\alpha$ (Fig. 6B). 
A
C

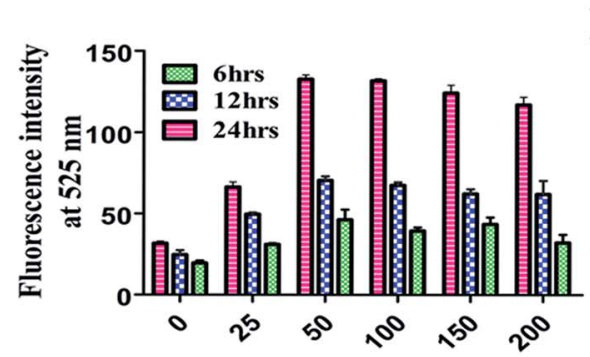

Concentration of TA $(\mu \mathrm{M})$
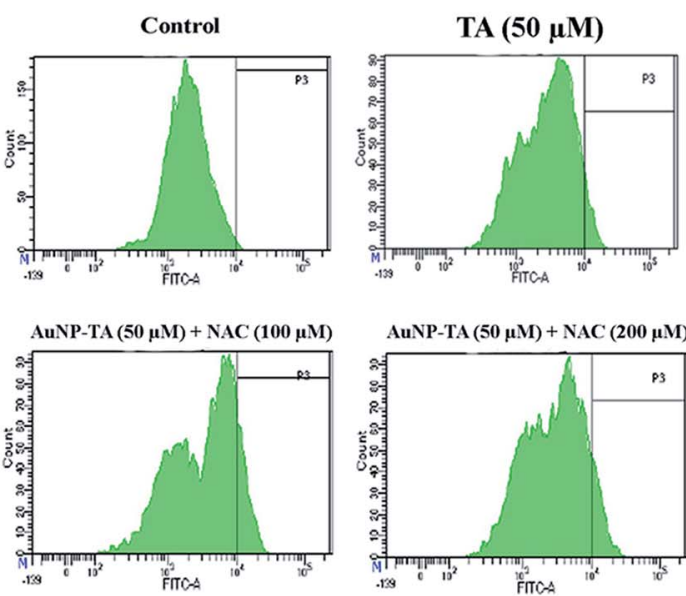

AuNP-TA $(50 \mu \mathrm{M})+\mathrm{NAC}(200 \mu \mathrm{M})$
B

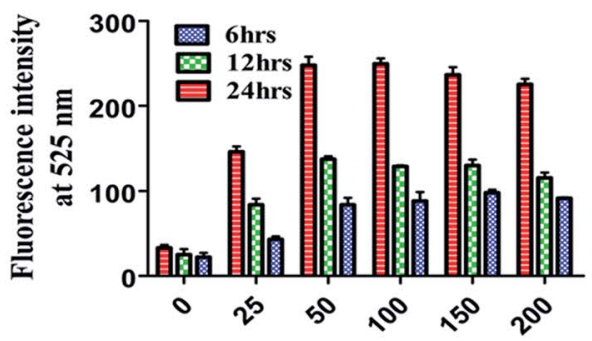

Concentration of AuNP-TA $(\mu M)$

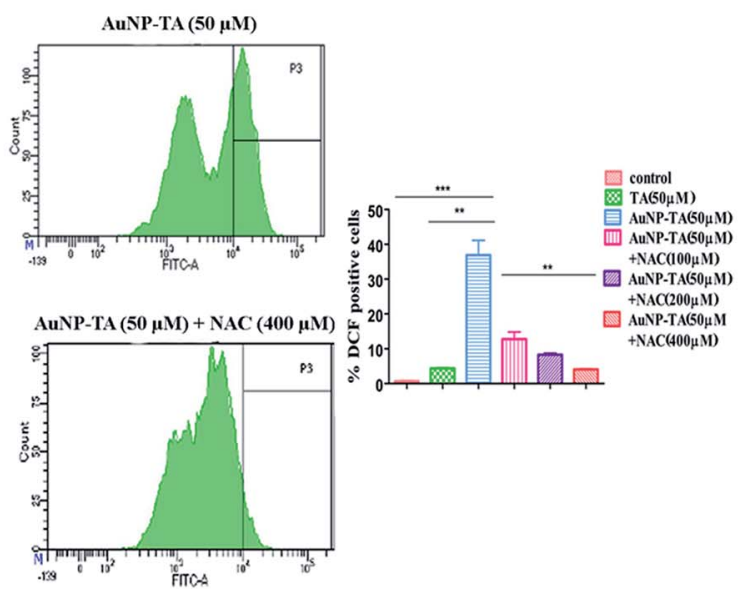

D

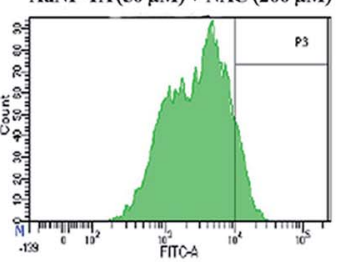

E

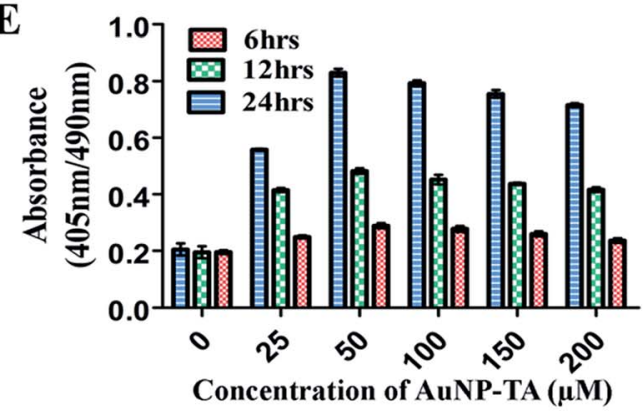

F

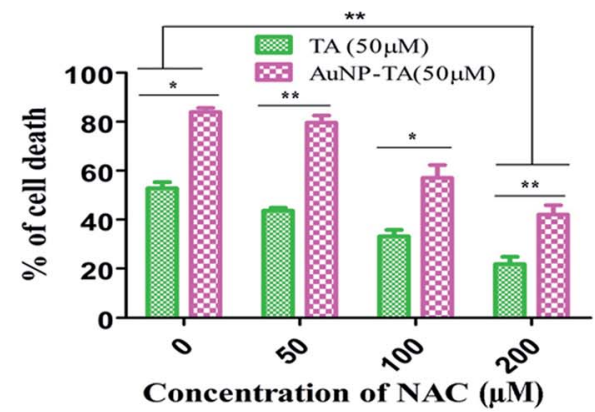

Fig. 3 (A and B) Fluorometric study of ROS generation induced by different concentrations (0, 25, 50, 100, 150, $200 \mu \mathrm{M})$ of TA and AuNP-TA for 6,12 and $24 \mathrm{~h}$, respectively. (C) Flow cytometric study of ROS generation in HCT116 cells after treatment with $50 \mu \mathrm{M}$ of TA or AuNP-TA for $24 \mathrm{~h}$ and different degrees of scavenging effect by three concentrations $(100,200$, and $400 \mu M)$ of NAC on AuNP-TA ROS generation. Values are mean \pm SD and represent one of the three representative experiments $(P<0.05)$. (D and E) DNA fragmentation studies in HCT116 cells, treated with different concentrations $(0,25,50,100,150,200 \mu \mathrm{M})$ of TA or AuNP-TA for 6,12 and $24 \mathrm{~h}$, respectively, using ELISA based colorimetric assay. The result is the mean \pm SD from triplicate independent experiments. (F) Percentage of dead cells, assayed using MTT dye after pretreatment of HCT116 cells with different concentrations of NAC, followed by treatment with $50 \mu \mathrm{M}$ of TA or AuNP-TA for $24 \mathrm{~h}$. The result is the mean \pm SD from triplicate independent experiments. 


\section{A \\ p53 \\ (53 kDa) \\ p21 \\ $(21 \mathrm{kDa})$ \\ $\beta$-actin \\ (42 kDa)}
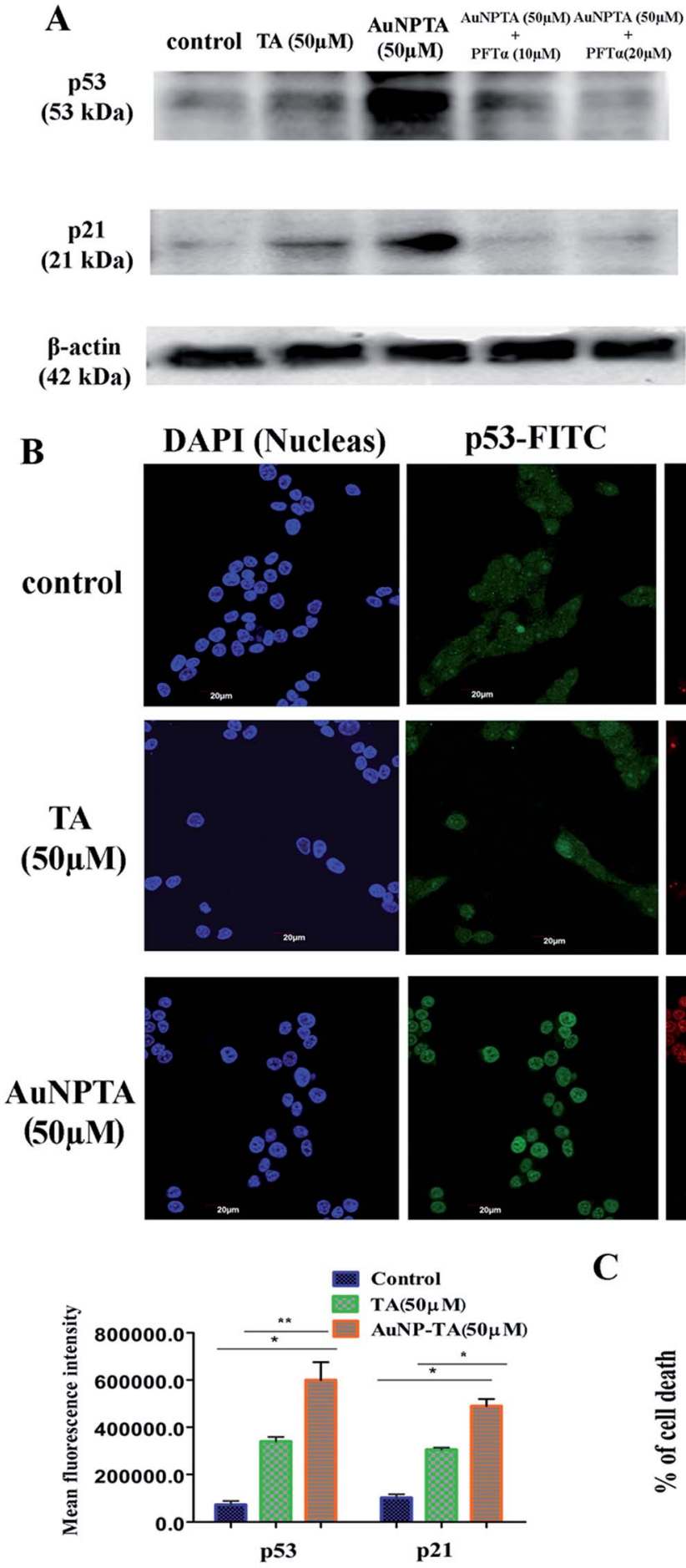
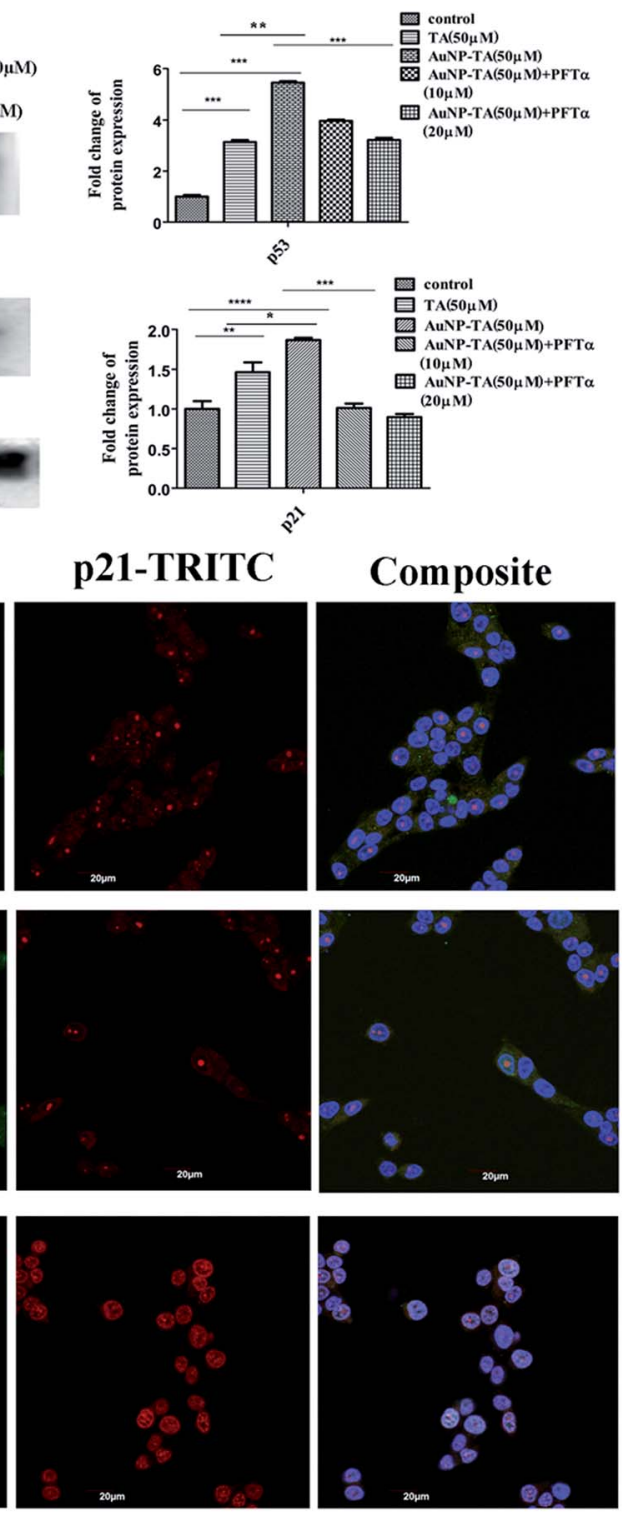

C

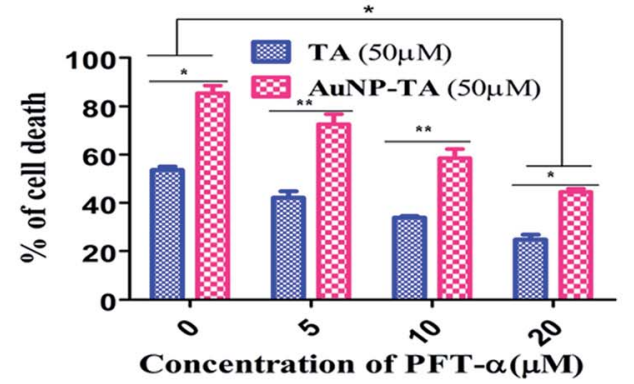

Fig. 4 (A) Cells were treated with $50 \mu \mathrm{M}$ of TA and AuNP-TA for $24 \mathrm{~h}$ and pre-treated with 10, $20 \mu \mathrm{M}$ of PFT- $\alpha$ prior to AuNP-TA treatment. Cells were lysed, and cell lysate was used for western blot analysis of p53 and p21 proteins. The bar graph shows densitometric analysis from representative western blots for the p53 and p21 $(P<0.05)$. (B) Immunocytochemistry images showing localization of p53 and p21 in HCT116 cells following treatment by $50 \mu \mathrm{M}$ of TA and AuNP-TA. DAPI was used for genomic DNA counterstaining. Translocation status of p53 and p21 in control cells (upper panel), $50 \mu \mathrm{M}$ TA treated cells (middle panel), and $50 \mu \mathrm{M}$ AuNP-TA treated cells (lower panel). Co-translocation (right merge panel) in the nuclei was observed for both of these proteins with respect to the untreated cells, where they were found to reside mainly in the cytoplasm. Scale bar $=20 \mu \mathrm{m}$. Mean fluorescence intensity (MFI) was calculated for both proteins $(P<0.05)$. (C) Percentage of dead cells was assayed using MTT dye after pre-treatment of HCT116 cells with different concentrations of PFT- $\alpha$, followed by treatment with $50 \mu \mathrm{M}$ of TA and AuNP-TA for $24 \mathrm{~h}$. The result is the mean \pm SD from triplicate independent experiments. 
A
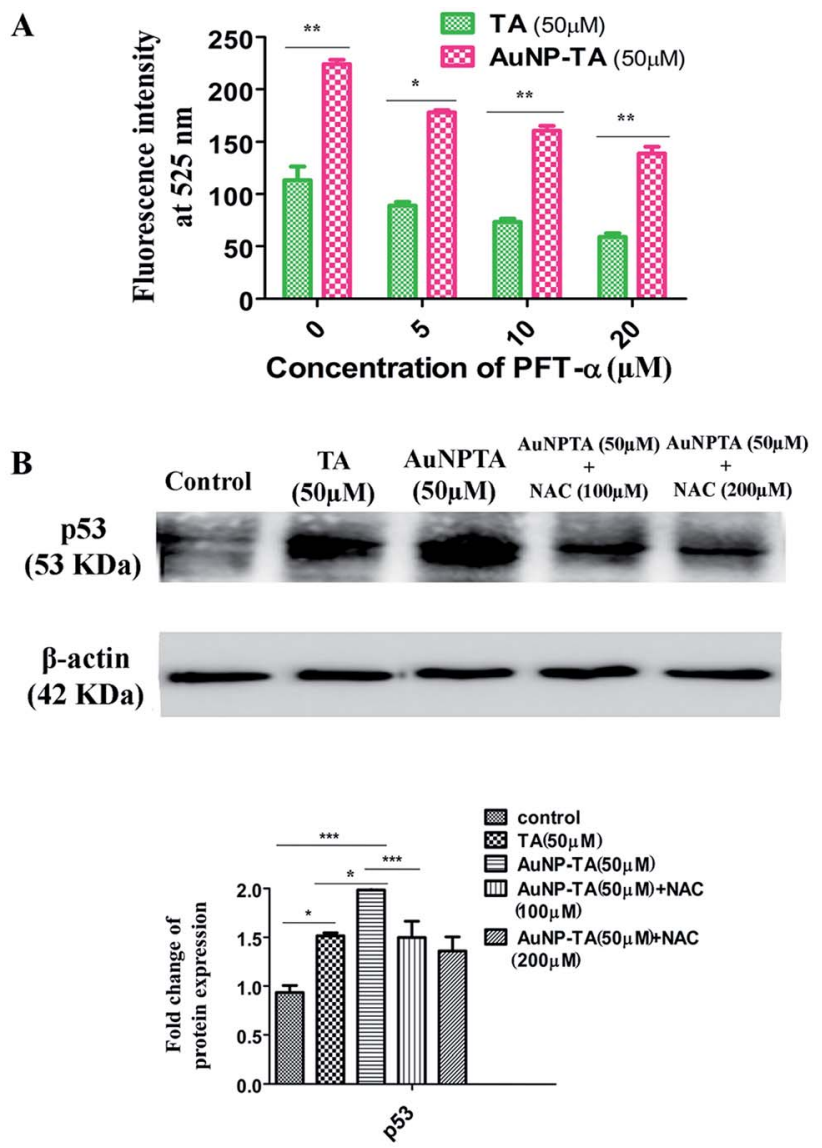

Fig. 5 (A) Fluorometric study of ROS generation in cells treated with $50 \mu \mathrm{M}$ of TA or AuNP-TA for $24 \mathrm{~h}$ after pre-treatment with varying concentrations of PFT- $\alpha$. (B) Cells pre-treated with 100 and $200 \mu \mathrm{M}$ of NAC were further treated with $50 \mu \mathrm{M}$ of TA or AuNP-TA for $24 \mathrm{~h}$. After lysis, the cell lysate was used for western blot analysis of p53 protein. The bar graph shows densitometric analysis of representative western blots for p53 $(P<0.05)$.

\section{TA binds to AKT, and TA, AuNP-TA regulate AKT expression levels}

PI3K/Akt mediates negative control of p53 expression level by targeting $\mathrm{p} 53$ for proteasomal degradation. ${ }^{47}$ In our case, the flow cytometry data showed that p53 expression increased after treatment with $50 \mu \mathrm{M} \mathrm{TA}$, but Akt levels decreased. The levels decreased further upon treatment with $50 \mu \mathrm{M}$ AuNP-TA. Pretreatment of HCT cells with PFT- $\alpha$ before treatment with 50 $\mu \mathrm{M}$ AuNP-TA decreased the levels of p53 and increased the levels of Akt as compared to treatment with $50 \mu \mathrm{M}$ AuNP-TA (Fig. 7A). Also, as demonstrated by western blot analysis, PI3K and Akt levels decreased upon treatment with $50 \mu \mathrm{M}$ AuNP-TA but increased when PFT- $\alpha$ was used (Fig. 7B).

As it has not been previously studied, we intended to analyse the interaction of Akt with TA on atomic level, and, hence, we searched Protein Databank (PDB) (http://www.rcsb.org/pdb) for suitable crystal structures (Fig. 7C). The residue interactions across TA-Akt interface are pictorially represented. The proteinprotein interactions of TA-Akt had been analyzed, and the atomatom interactions across the interface showed that TA interacts with S478, S477, K214, and R74 residues of Akt via hydrogen bonding. To explore the strength of interaction between the ligand and complex, the binding free energy $\left(\Delta G_{\text {bind }}\right)$ was calculated using MM-GBSA method. Negative $\Delta G$ values showed a higher binding affinity between TA and Akt (Fig. 7D).

\section{TA and AuNP-TA induced cell death in HCT116 cells follows the mitochondrial pathway of apoptosis}

Cellular apoptosis follows intrinsic (mitochondrial) or extrinsic pathway and sometimes both. ${ }^{48}$ Mitochondrial membrane potential was lowered (Fig. 8A) and cytosolic cytochrome $c$ level was raised (Fig. 8E) $24 \mathrm{~h}$ after the addition of $50 \mu \mathrm{M}$ of TA and AuNPTA. When HCT116 cells were pre-treated with PFT- $\alpha$, mitochondrial potential increased and cytochrome $c$ levels decreased as compared to those upon treatment with $50 \mu \mathrm{M}$ of AuNP-TA alone.

To test the presence of mitochondrial pathway, levels of caspase-9 and caspase-3, pro-apoptotic Bax and Bad, and antiapoptotic Bcl-2 were measured, and the mitochondrial membrane potential was determined. Treatment with $50 \mu \mathrm{M}$ TA and $50 \mu \mathrm{M}$ AuNP-TA for $24 \mathrm{~h}$ significantly increased the levels of caspase-9 (Fig. 8C) and caspase-3 (Fig. 8D) and raised the levels of Bax and Bad; these were, however, reduced upon treatment with $10 \mu \mathrm{M}$ or $20 \mu \mathrm{M}$ PFT- $\alpha$. Also, the Bcl2 level, which was lowered upon treatment with TA and AuNP-TA, was increased when cells were treated with PFT- $\alpha$ (Fig. 8B).

\section{Discussion}

We consume tannic acid while eating grapes, pomegranates, and cereals. There are previous reports of tannic acid preventing breast cancer, ${ }^{49,50}$ ovarian cancer, ${ }^{51}$ gingival cancer $^{52}$ and brain cancer. ${ }^{24}$ However, the exact mechanism or pathway by which tannic acid kills colon cancer cells was not fully understood.

In the present study, during a screening of TA against different cancer cell lines for cytotoxicity, a strong effect was noted in colorectal carcinoma cells with an $\mathrm{IC}_{50}$ of $48.37 \mu \mathrm{M}$. To reduce the $\mathrm{IC}_{50}$ dose value and, possibly, increase efficiency, AuNP-TA was synthesized. Indeed, the $\mathrm{IC}_{50}$ value of $\mathrm{TA}$ in HCT116 cells was reduced to half when AuNP-TA was used. Also, following treatment with AuNP-TA of colon cancer cells (HCT116), blebbing of the membrane, chromosome condensation and fragmentation of DNA (hallmarks of apoptosis) were observed via A.O./EtBr and DAPI staining and confirmed via Annexin V/PI staining.

TA and AuNP-TA-induced apoptosis proved to be ROSdependent because an increase in the concentration of TA and AuNP-TA and time caused a significant increase in the production of ROS, while pre-treatment with NAC increased HCT116 cell viability. More ROS were generated upon treatment with AuNPTA as compared to treatment with TA at the same concentration. This led to DNA damage, which was decreased when NAC was used. The TA or AuNP-TA induced DNA damage of HCT116 cells led to increased expression of p53 and of the downstream effector gene $p 21$. Confocal microscopy revealed that overexpressed p53 and p 21 were co-localized in the nucleus. Increased p53 expression caused cell death, and the percentage of dead cells decreased when HCT116 cells were pre-treated with 
A

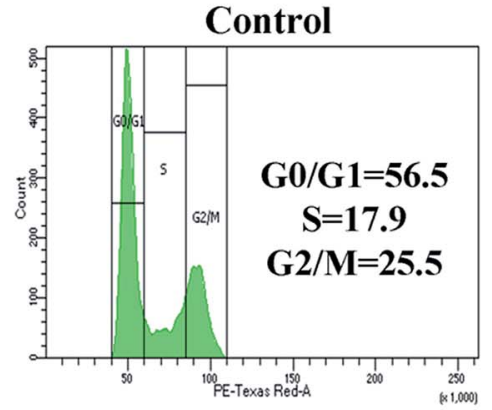

TA $(50 \mu M)$

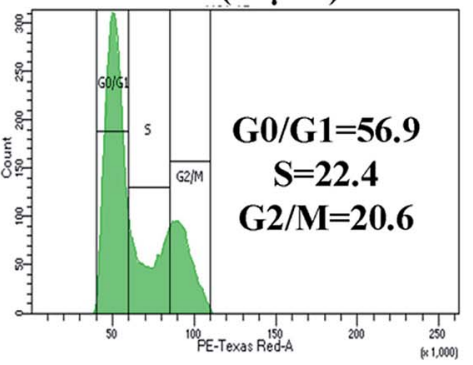

AuNP-TA (50 $\mu \mathrm{M})$

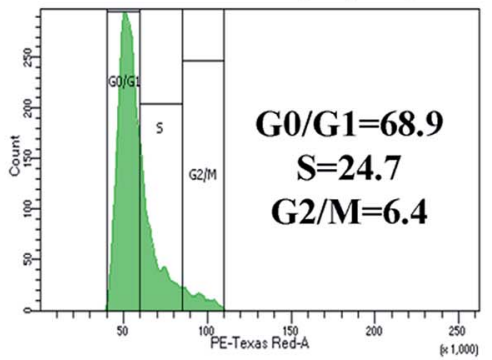

AuNP-TA $(50 \mu M)+P F T a(10 \mu M)$
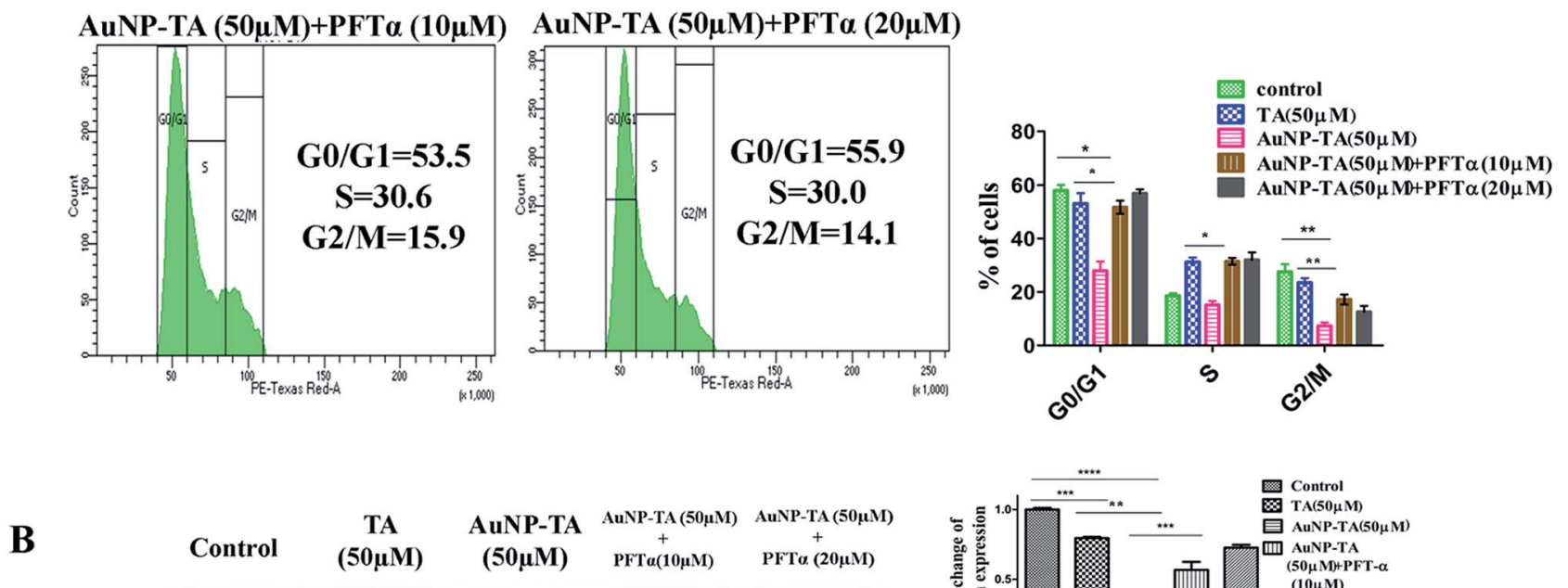

Cyclin A

(54 kDa)
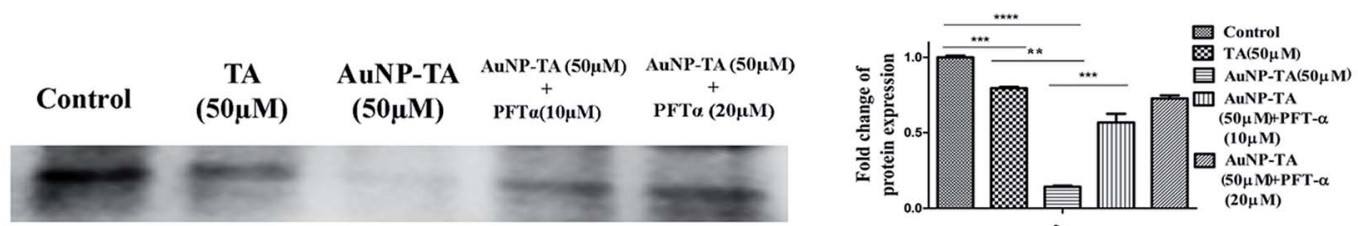

Cyclin B1

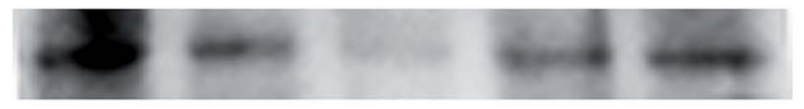

Cdk1

(34 kDa)
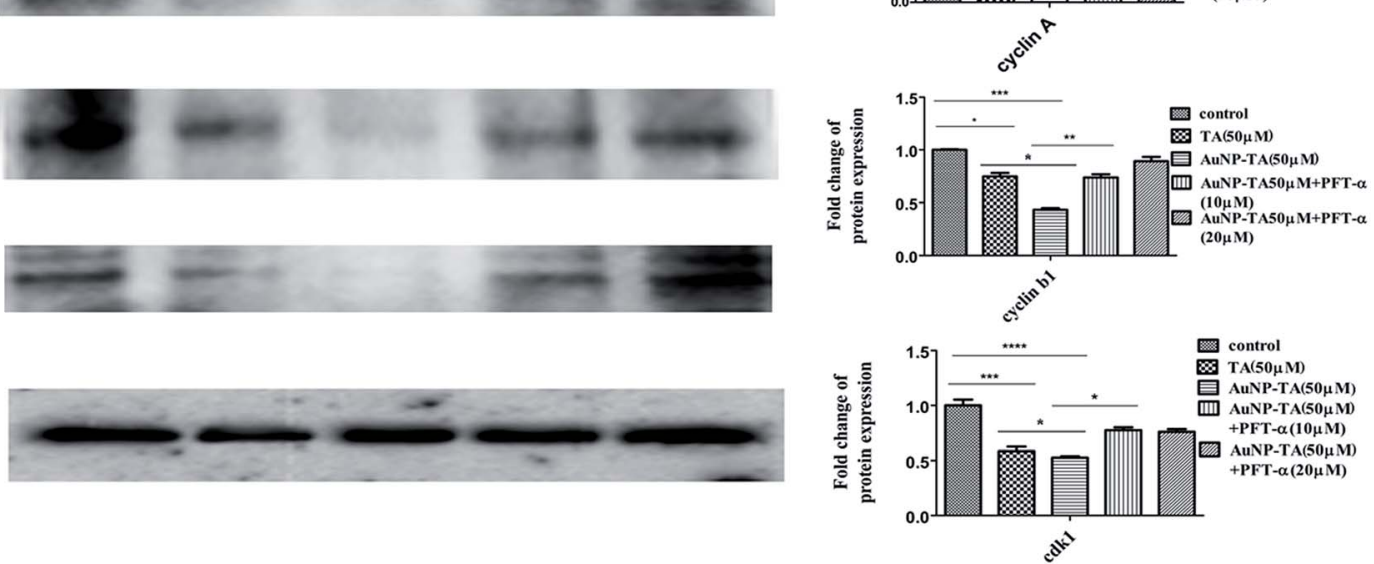

Fig. 6 (A) Effect on cell cycle arrest in HCT116 cells of treatment with $50 \mu \mathrm{MTA}$ and $50 \mu \mathrm{M}$ AuNP-TA and treatment with 10, $20 \mu \mathrm{M}$ PFT- $\alpha$ prior to AuNP-TA treatment. The result is the mean \pm SD from triplicate independent experiments. (B) Cells were treated with $50 \mu M$ of TA and AuNP-TA for $24 \mathrm{~h}$ and pre-treated with 100,200 $\mu \mathrm{M}$ of NAC prior to AuNP-TA treatment. Cells were lysed and the cell lysate was used for western blot analysis of cyclin A, cyclin B1, and cdk1 protein. The bar graph shows densitometric analysis from representative western blots for cyclin A, cyclin $\mathrm{B} 1$ and $\mathrm{cdk}(P<0.05)$.

pifithrin- $\alpha$. Induced DNA damage and p53/p21 expression were higher upon treatment with AuNP-TA as compared to those upon treatment with TA at the same concentration. It was also determined that ROS and p53 regulated each other bi-directionally. p21 inhibited the kinase activity of cyclin A, cyclin B, and CDK1, which controlled the G2/M transition, thereby, leading to cell cycle arrest.
From flow-cytometry data, it was found that ROS-induced increase in p53 expression was accompanied by a simultaneous decrease in Akt expression. Thus, TA may directly interact with Akt protein, and this inhibition of Akt may lead to p53 up-regulation. So we performed docking studies to find out if TA interacted with the Akt protein. These studies revealed that TA interacted with various residues of Akt, and 


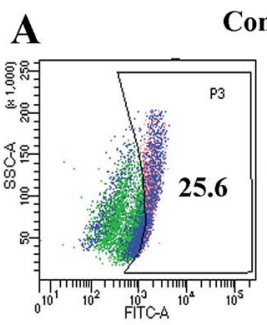

Control
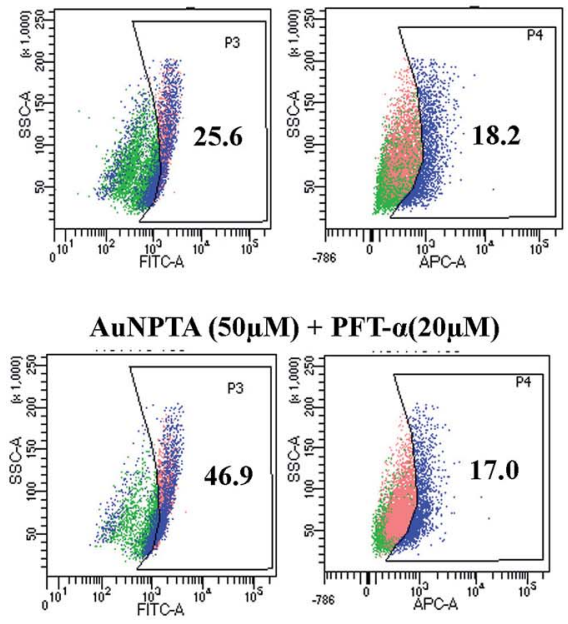

B

Control TA $(50 \mu \mathrm{M})$
TA $(50 \mu M)$

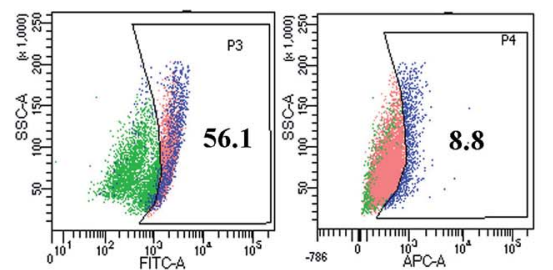

AuNPTA $(50 \mu M)$

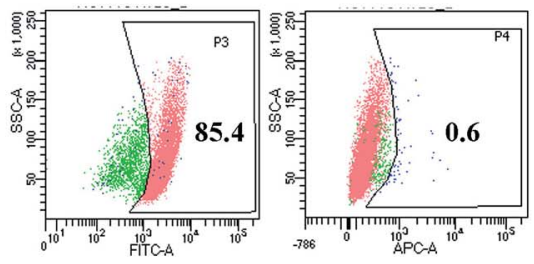

C

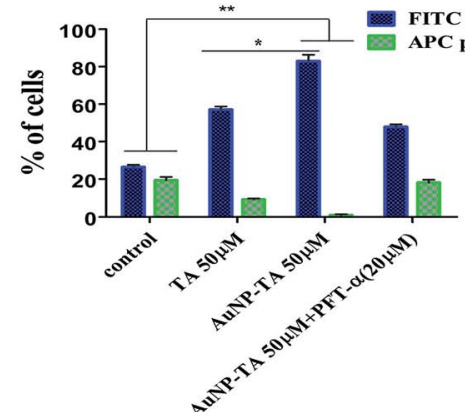

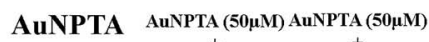
$(50 \mu \mathrm{M})$

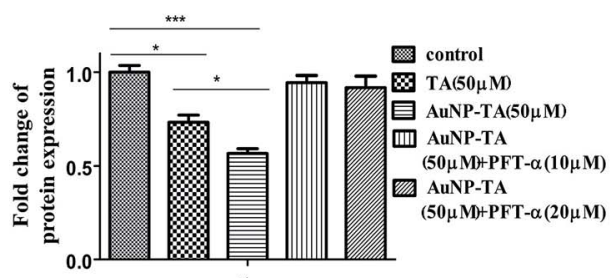

(110 kDa)
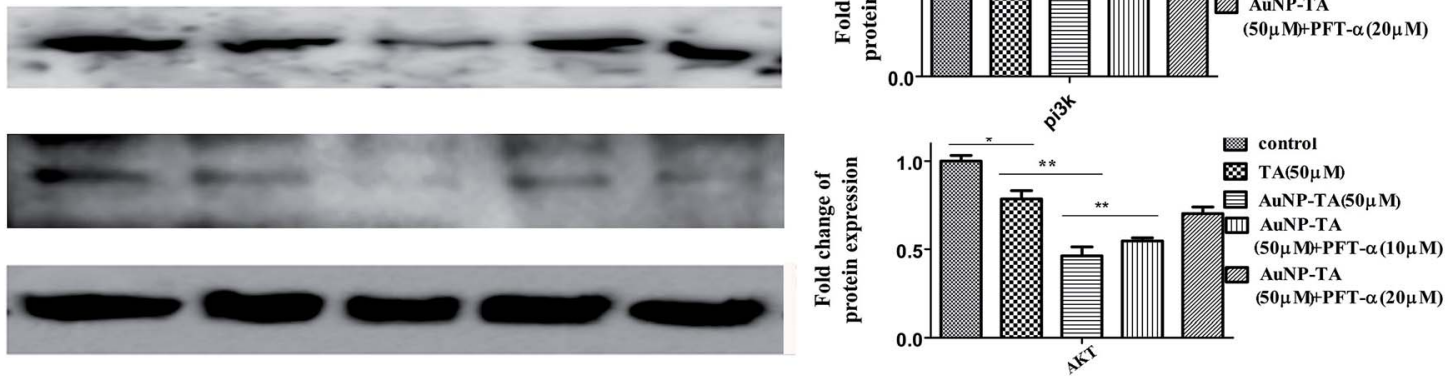

$\beta$-actin (42 kDa)

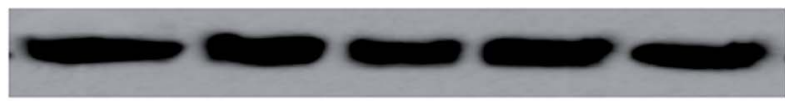

TC positive(p53)
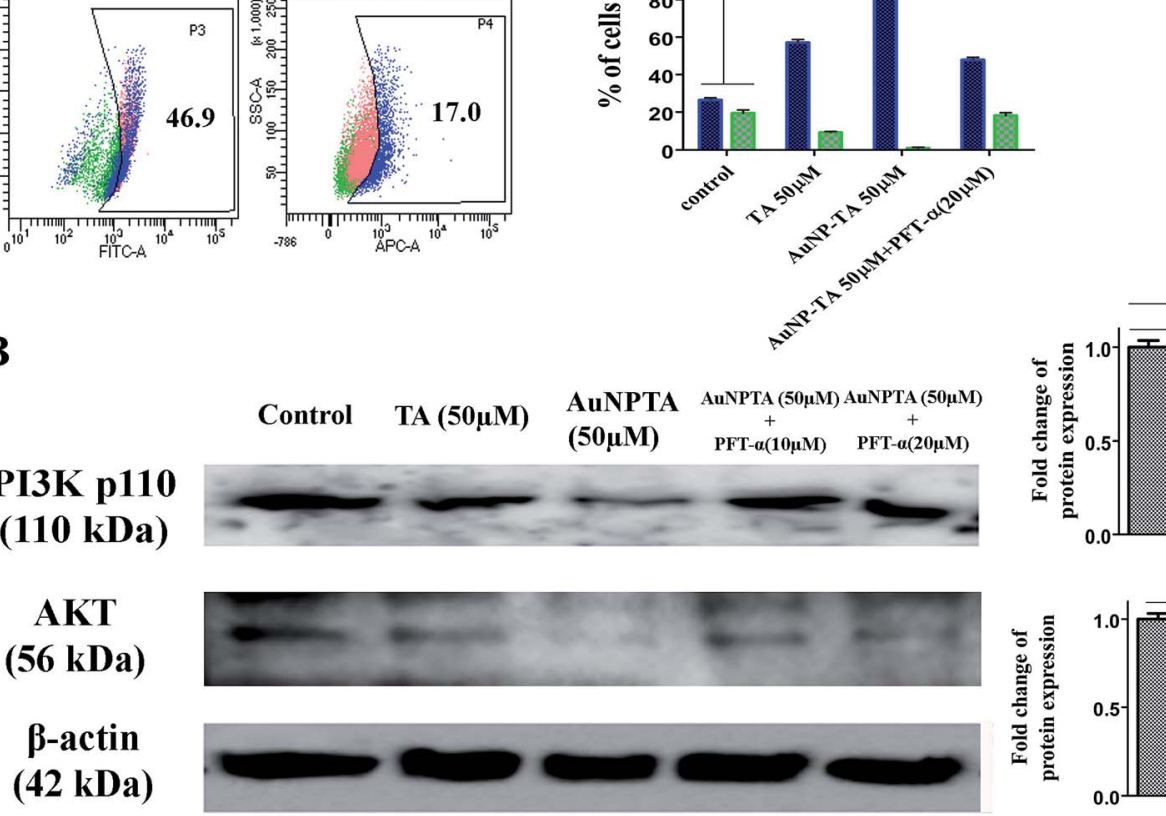

D
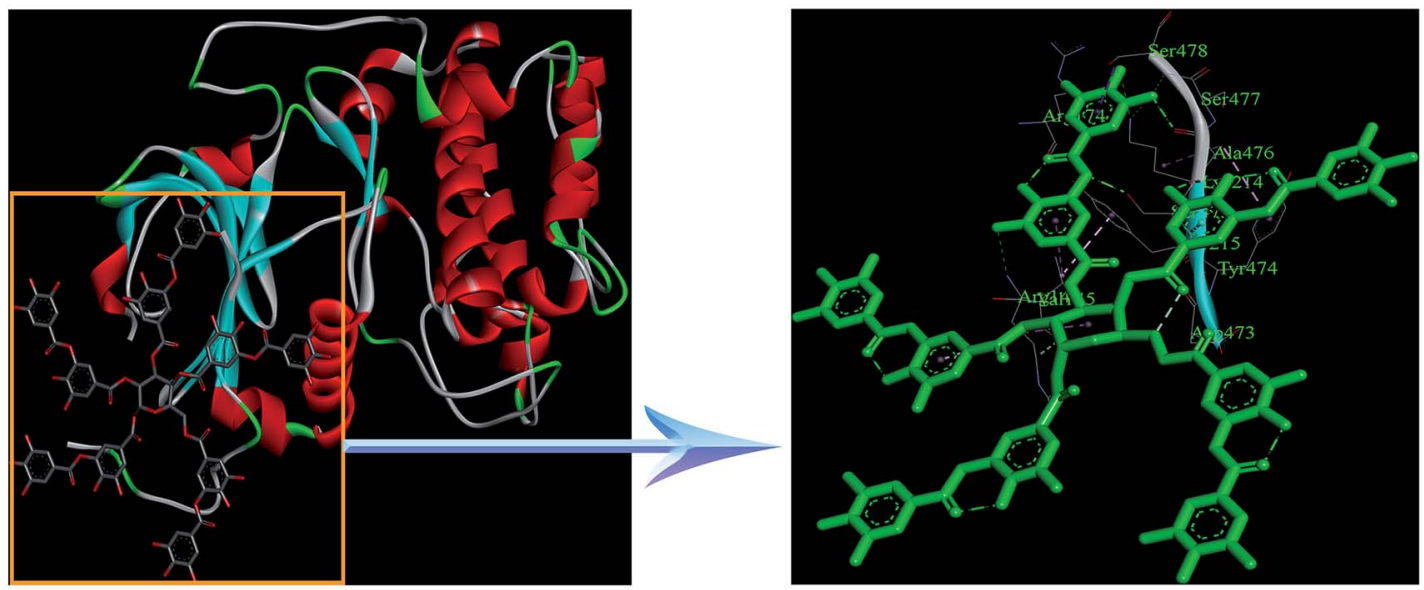

Fig. 7 (A) Flow cytometric analysis to determine p53 and Akt protein expression levels in HCT116 cells upon treatment with $50 \mu \mathrm{M}$ of TA or AuNP-TA and pre-treatment with PFT- $\alpha$ prior to AuNP-TA treatment. The result is the mean \pm SD from triplicate independent experiments. (B) Cells were treated with $50 \mu \mathrm{M}$ of TA and AuNP-TA for $24 \mathrm{~h}$ and pre-treated with 10, $20 \mu \mathrm{M}$ of PFT- $\alpha$ prior to AuNP-TA treatment. Cells were lysed, and the cell lysate was used for western blot analysis of PI3K-p110 and AKT proteins. The bar graph shows densitometric analysis from representative western blots for the PI3K-p110 and AKT $(P<0.05)$. (C) The atomic level interaction of Akt with TA was studied using SwissDock software. (D) The specific residue interactions across the tannic acid-Akt interface are pictorially represented.

the derived negative Gibbs free energy indicated a high binding affinity between TA and Akt. Lowered expression of Akt also inhibited the survival of colon cancer cells.
Induction of apoptosis by TA and AuNP-TA in HCT116 cells was further confirmed by activation of caspase 3 , caspase 9 , and pro-apoptotic Bax and Bad; pre-treatment with p53 inhibitor 
A

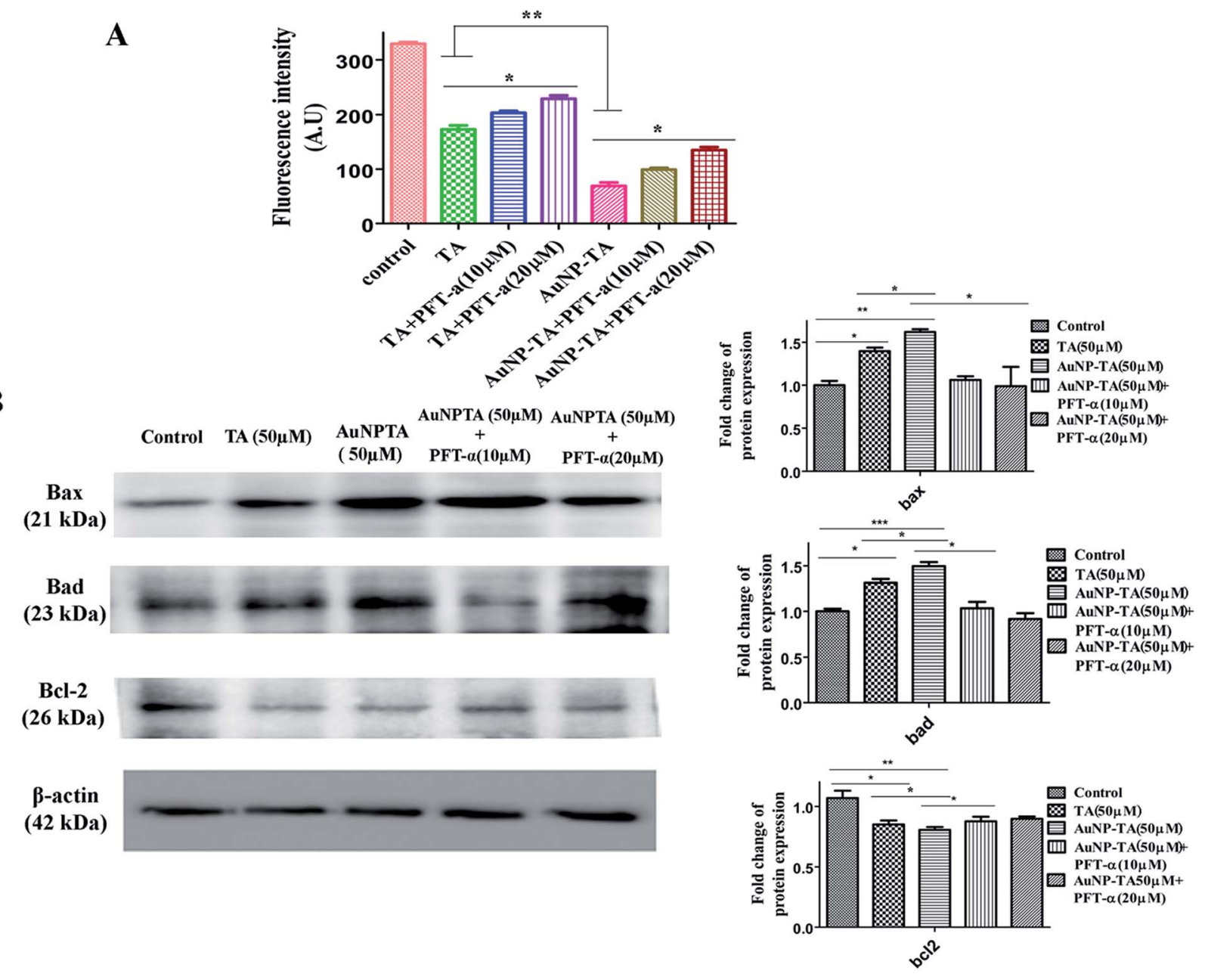

B

C

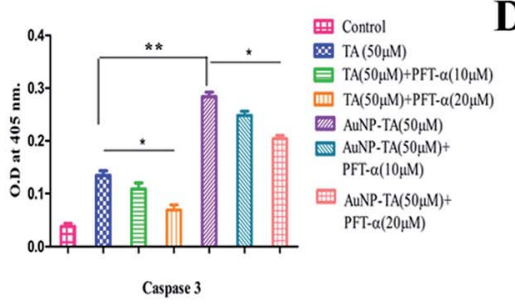

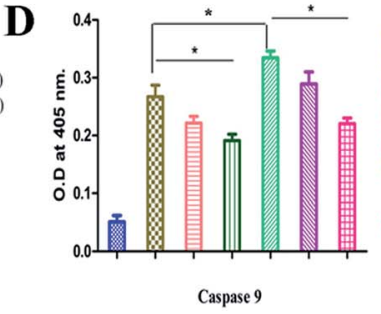
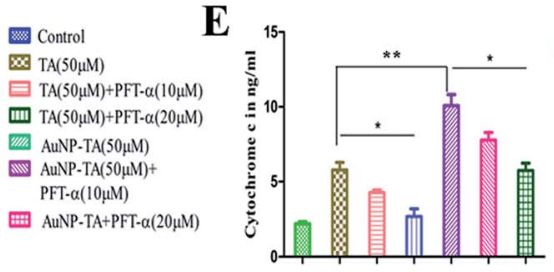

Fig. 8 (A) Mitochondrial membrane potential was measured using spectrofluorimetry in $50 \mu \mathrm{M}$ TA or $50 \mu \mathrm{M}$ AuNP-TA and PFT- $\alpha$ pre-treated HCT116 cells, prior to TA and AuNP-TA treatment. Measurement by spectrofluorimetry using rhodamine 123 is reflected by a change in O.D. Values are mean $\pm \mathrm{SD}$ and represent one of three representative experiments $(P<0.05)$. (B) Cells were treated with $50 \mu \mathrm{M}$ of TA and AuNP-TA for $24 \mathrm{~h}$ and pre-treated with 10,20 $\mu \mathrm{M}$ of PFT- $\alpha$ prior to AuNP-TA treatment. Cells were lysed, and cell lysate was used for western blot analysis of $\mathrm{Bax}, \mathrm{Bad}$, and $\mathrm{Bcl}-2$ proteins. Bar graph shows densitometric analysis from representative western blots for $\mathrm{Bax}, \mathrm{Bad}$, and $\mathrm{Bcl}-2(P<0.05)$. $(\mathrm{C}$ and D) Cells after treatment with $50 \mu \mathrm{M}$ of TA and AuNP-TA for $24 \mathrm{~h}$ or pre-treated with 10, $20 \mu \mathrm{M}$ of PFT- $\alpha$ prior to TA and AuNP-TA treatment were assayed employing ELISA based colorimetric assay using kits for determining the levels of activated caspase-3 and caspase-9. Increase in O.D. shows activation of caspase- 3 and caspase-9. (E) Cytochrome $c$ level alteration determined via spectrofluorometric analysis.

decreased the activation. At $50 \mu \mathrm{M}$ dosage of TA and AuNP-TA, the appearance of caspases and pro-apoptotic proteins was more by AuNP-TA treatment as compared to treatment with TA. Anti-apoptotic Bcl-2 showed decreased expression upon treatment with AuNP-TA as compared to TA, but the expression increased when the p53 inhibitor was used. Loss of mitochondrial membrane potential (MMP) was more pronounced when treatment was done with AuNP-TA as compared to TA, but pretreatment with PFT- $\alpha$ led to a gain in membrane potential.

Another factor which seems to contribute to better anticancer activity of AuNP-TA is its improved stability. AuNP-TA solution was stable for 50 days after its preparation, confirmed by UV-Vis absorption spectroscopy measurements (Fig. S1†). Also, toxicity study conducted on a normal cell line 
(human epithelial kidney cell line, HEK 293) showed that 50\% of cells were dead at $16.67 \pm 3.24 \mu \mathrm{M}$ dose of tannic acid but $80.45 \pm 4.62 \mu \mathrm{M}$ dose of AuNP-TA. Therefore, AuNP-TA was much less toxic to normal cells than TA.

Drug release kinetics also show a more sustained release of AuNP-TA as compared to that of TA (Fig. S2 $\dagger$ ). Sustained release of AuNP-TA can also contribute to its better anticancer activity as compared to TA. Therefore, AuNP-TA was superior to TA in many respects.

\section{Conclusion}

The results of this study suggest that TA leads to apoptosis in HCT116 cells via the ROS/p53/Akt axis, though it is much less potent than AuNP-TA. It is, however, necessary to undertake further studies to explore the function of AuNP-TA in various in vivo cancer models to help with development of a novel treatment for cancer that would lead to effective colon cancer cell death.

\section{Conflict of interest}

The authors have no conflict of interest.

\section{Acknowledgements}

The research is supported by the CSIR, Government of India. A research fellowship from UGC-SRF, Govt. of India to Mrs Sayoni Nag is gratefully acknowledged. The authors gratefully acknowledge Mr Tanmoy Dalui, Sri. Binayak Pal and Smt. Banasri Das of Central Instrumentation Facility, CSIR-Indian Institute of Chemical Biology for providing flow cytometry and confocal microscopy facilities. The authors are very grateful to National Medicinal Plant Board (NMPB), Department of Biotechnology (DBT), and Department of Science \& Technology (DST), Government of India for partial funding support. We are also extremely grateful to Dr Basudeb Achari, ex-senior scientist, CSIR-IICB for necessary English corrections.

\section{References}

1 P. Pratheeshkumar, C. Sreekala, Z. Zhang, A. Budhraja, S. Ding, Y.-O. Son, et al., Adv. Anticancer Agents Med. Chem., 2012, 12(10), 1159-1184.

2 M. Rizwanullah, S. Amin and J. Ahmad, J. Drug Targeting, 2017, 25, 58-74.

3 M. Fantini, M. Benvenuto, L. Masuelli, G. V. Frajese, I. Tresoldi, A. Modesti, et al., Int. J. Mol. Sci., 2015, 16, 9236-9282.

4 C. J. Bridgeman, T. U. Nguyen and V. Kishore, J. Biomater. Sci., Polym. Ed., 2018, 29(4), 412-427.

5 İ. Gülçin, Z. Huyut, M. Elmastaş and H. Y. Aboul-Enein, Arabian J. Chem., 2010, 3(1), 43-53.

6 G. Dong, H. Liu, X. Yu, X. Zhang, H. Lu, T. Zhou, et al., Nat. Prod. Res., 2018, 32(18), 2225-2228.

7 P. Orlowski, E. Tomaszewska, M. Gniadek, P. Baska, J. Nowakowska, J. Sokolowska, Z. Nowak, M. Donten,
G. Celichowski, J. Grobelny and M. Krzyzowska, PLoS One, 2014, 9, e104113.

8 M. Carbonaro, G. Grant and A. Pusztai, Eur. J. Clin. Nutr., 2001, 40(2), 84-90.

9 K. B. Pandey and S. I. Rizvi, Oxid. Med. Cell. Longevity, 2009, 2, 270-278.

10 L. Marín, E. M. Miguélez, C. J. Villar and F. Lombó, Biomed Res. Int., 2015, 2015, 905215.

11 M. D'Archivio, C. Filesi, R. Varì, B. Scazzocchio and R. Masella, Int. J. Mol. Sci., 2010, 11, 1321-1342.

12 A. P. Subramanian, S. K. Jaganathan, A. Manikandan, K. N. Pandiaraj, N. Gomathi and E. Supriyanto, RSC Adv., 2016, 6, 48294-48314.

13 M. R. Kamala Priya and P. R. J. A. N. Iyer, Int. J. Pharmacol. Res., 2015, 5, 443-448.

14 P. Kuppusamy, M. M. Yusoff, G. P. Maniam and N. Govindan, Saudi Pharm. J., 2016, 24, 473-484.

15 F. K. Alanazi, A. A. Radwan and I. A. Alsarra, Saudi Pharm. J., 2010, 18, 179-193.

16 M. Sengani, A. M. Grumezescu and V. D. Rajeswari, OpenNano, 2017, 2, 37-46.

17 A. Kumar, B. Mazinder Boruah and X.-J. Liang, J. Nanomater., 2011, 2011, 17.

18 A. A. Dayem, M. K. Hossain, S. B. Lee, K. Kim, S. K. Saha, G. M. Yang, et al., Int. J. Mol. Sci., 2017, 18(1), 1-21.

19 G. Waris and H. Ahsan, J. Carcinog., 2006, 5, 14.

20 N. S. Pellegata, R. J. Antoniono, J. L. Redpath and E. J. Stanbridge, Proc. Natl. Acad. Sci., 1996, 93(26), 1520915214.

21 J. S. Brown and U. Banerji, Pharmacol. Ther., 2017, 172, 101115.

22 L.-F. Shyur, C.-H. Chen, C.-P. Lo, S.-Y. Wang, P.-L. Kang, S.-J. Sun, et al., J. Biomed. Sci., 2004, 11(6), 928-939.

23 H. Liu, X. Liu, C. Zhang, H. Zhu, Q. Xu, Y. Bu, et al., J. Cancer, 2017, 8, 1586-1597.

24 J. Zhang, D. Chen, D. Han, Y. Cheng, C. Dai, X. Wu, et al., Oncol. Lett., 2018, 17, 6845-6850.

25 D. Cosan, A. Soyocak, A. Basaran, I. Degirmenci and H. V. Gunes, Saudi Med. J., 2009 Feb 7, 30(2), 191-195.

26 X. Huang and M. A. El-Sayed, J. Adv. Res., 2010, 1, 13-28.

27 T. Jurkin, M. Guliš, G. Dražić and M. Gotić, Gold Bull., 2016, 49(1-2), 21-33.

28 R. S. Y. Wong, J. Exp. Clin. Cancer Res., 2011, 30(1), 87.

29 X. Wu, Med. Sci. Monit. Basic Res., 2015, 21, 15-20.

30 S. H. Lee, X. W. Meng, K. S. Flatten, D. A. Loegering and S. H. Kaufmann, Cell Death Differ., 2013, 20(1), 64-76.

31 A. J. León-González, C. Auger and V. B. Schini-Kerth, Biochem. Pharmacol., 2015, 98(3), 371-380.

32 F. Thayyullathil, S. Chathoth, A. Hago, M. Patel and S. Galadari, Free Radical Biol. Med., 2008, 45(10), 1403-1412. 33 M. Halasi, M. Wang, T. S. Chavan, V. Gaponenko, N. Hay and A. L. Gartel, Biochem. J., 2013, 454(2), 201-208.

34 J. E. Klaunig, Z. Wang, X. Pu and S. Zhou, Toxicol. Appl. Pharmacol., 2011, 254(2), 86-99.

35 J. E. Klaunig, L. M. Kamendulis and B. A. Hocevar, Toxicol. Pathol., 2010, 38, 96-109.

36 N. D. Lakin and S. P. Jackson, Oncogene, 1999, 18, 7644-7655. 
37 D. W. Meek, DNA Repair, 2004, 3, 1049-1056.

38 L. A. Kachnic, B. Wu, H. Wunsch, K. L. Mekeel, J. S. DeFrank, W. Tang, et al., J. Biol. Chem., 1999, 274(19), 13111-13117.

39 S. Rocha, K. J. Campbell, K. C. Roche and N. D. Perkins, BMC Mol. Biol., 2003, 4, 9.

40 M. Redza-Dutordoir and D. A. Averill-Bates, Biochim. Biophys. Acta, Mol. Cell Res., 2016, 1863(12), 2977-2992.

41 K. O'Keefe, H. Li and Y. Zhang, Mol. Cell. Biol., 2003, 23(18), 6396-6405.

42 T. M. Johnson, Z. X. Yu, V. J. Ferrans, R. A. Lowenstein and T. Finkel, Proc. Natl. Acad. Sci. U. S. A., 1996, 93(21), 11848-11852.

43 A. Agarwal, A. Kasinathan, R. Ganesan, A. Balasubramanian, J. Bhaskaran, S. Suresh, et al., Nutr. Res., 2018, 51, 67-81.
44 L. Tian, D. Yin, Y. Ren, C. Gong, A. Chen and F. J. Guo, Mol. Med. Rep., 2012, 5(1), 126-132.

45 P. H. Shaw, Pathol., Res. Pract., 1996, 192, 669-675.

46 E. Senturk and J. J. Manfredi, Methods Mol. Biol., 2013, 962, 49-61.

47 G. Nayak and G. M. Cooper, Cell Death Dis., 2012, 3, e400. 48 S. Elmore, Toxicol. Pathol., 2007, 35, 495-516.

49 B. W. Booth, B. D. Inskeep, H. Shah, J. P. Park, E. J. Hay and K. J. L. Burg, Int. J. Breast Cancer, 2013, 2013, 369609.

50 K. Tikoo, M. S. Sane and C. Gupta, Toxicol. Appl. Pharmacol., 2011, 251(3), 191-200.

51 Y. Sun, T. Zhang, B. Wang, H. Li and P. Li, Anticancer Drugs, 2012, 23(9), 979-990.

52 P. Darvin, S. J. Baeg, Y. H. Joung, S. P. Nipin, D. Y. Kang, H. J. Byun, et al., Int. J. Oncol., 2015, 47(3), 1111-1120. 